\title{
COLONIAL LAW AND THE GENESIS OF THE INDONESIAN STATE
}

\author{
Daniel S. Lev
}

It should be obvious that new states owe a great deal to colonial precedent, for even the most shattering revolutions, very rare among new states, cannot wipe out the past. Yet, as Harry Benda made us see over twenty years ago in his debate with Herbert Feith, it is easy to take seriously the present's claim to exist in the present only, unique and devoid of debt to a despicable and embarrassing history. Benda himself and more recently Heather Sutherland and Ben Anderson have illuminated the unbroken chain of evolution that runs from colony to independent state by focusing on institutional continuity. 1 My objective in this article is to build on their work, using legal history to trace significant features that were sewn into the fabric of the colonial state and have yet to unravel. Law is an especially rich lode for this kind of mining, because it records (literally) the structure of the state and reflects (virtually) the distribution of political, social, and economic advantages. In modern states generally law and legal process are an essential ingredient of the (Gramscian) hegemony that defines and justifies relationships of ruler and subject. How large an ingredient naturally varies from state to state, depending on local culture, ideology, political structure, and much else. But in whatever measure, as law and legal institutions abstractly represent a configuration of power relationships, masking it with a cover of legitimate authority, they bear much significance beyond themselves. It is this significance, more than the law itself, that needs to be read.

Only four topics will be dealt with here: plural legal and judicial organization in the colony; adat law policy; private legal roles; and the transmission of colonial legal tradition into the independent state. The raw argument is that colonial law, which established the genetic pattern of the Indonesian state, was intended primarily to make exploitation efficient. Plural law, plurally administered, was predicated on the assignment of quite different functions and prerogatives to, above all, the Dutch and Indonesian communities. The institutions developed to administer the Indonesian side of colonial society carried over into independence, bearing with them instruments of repression no less useful to the later than the earlier regimes.

\section{Pluralism}

Nothing needs to be said here about precolonial law, except that the Dutch changed its conditions, less by imposing new law than by imposing new political

1. Harry J. Benda, "The Pattern of Reforms in the Closing Years of Dutch Rule in Indonesia," Journal of Asian Studies 25, 4 (1966): 589-605; Heather Sutherland, The Making of a Bureaucratic Elite: The Colonial Transformation of the Javanese Priyayi (Singapore: Heinemann, 1979); Benedict R. O'G. Anderson, "Old State, New Society: Indonesia's New Order in Comparative Historical Perspective," Journal of Asian Studies 42, 3 (1983): 477-96. 
power. From the start, the Dutch East-Indies Company (VOC) resolved to respect local law-another way of saying that, by and large, they could not have cared less--except where commercial interests were at stake. What they did not respect, and given their ambitions could not, were local economic and political relationships, always fundamental sources of local law.

In the development of the colony proper during the nineteenth century, the key decision, as Furnivall observed, was to extract agricultural commodities as expeditiously as possible. In itself this was hardly unusual, though the Dutch went about it with striking single-mindedness. What was unusual was the way in which law was used to serve their ends. In all colonies efficient extraction implied ethnic specialization and pluralism, but few others, if any, created so exact a legal-institutional configuration of pluralism as the Netherlands-Indies. 2 The unequivocal interest of the VOC and the later colonial administration in economic exploitation called for an unmistakable demarcation between exploiters and exploitees. Indirect rule was an inexpensive way of achieving this, but implementation required intricate political and institutional adjustments. In addition, there were serious arguments over issues of legal policy, from the 1790s through the $1820 \mathrm{~s}$, that gave the winners incentive to imbed their ideas in statutory concrete. 3 The debates were fundamental enough to be revived over the next century during every policy crisis that eventuated in major legal reforms. At issue, basically, was whether to establish a unified or a segregated colonial society: in legal terms, one law for all population groups or plural law for plural groups. The first view, inspired by liberal ideas and the English example in India, tended to the creation of a liberal state of sorts. The second, committed to rapid returns from the colony and informed by a sharp distinction between European and Indonesian virtues-which hardly favored the Indonesian character-assumed the creation not of a state but of an administrative system. This second view won; and as the argument was cast in legal terms, its outcome was consolidated legally. In the discretionary rule period of the early colony, little more was written in law than necessary. In the liberal constitutionalist period of the second half of the nineteenth century, pluralist legal premises, by then taken for granted, were elaborated in detail.

Practically everything in the legal system, as it evolved, followed from these premises, albeit more and more obscurely. As the standard legal histories of the Netherlands-Indies have it, following the founding work of the $1810 \mathrm{~s}$ and 1820s, much influenced by developments under the VOC, Daendels, and Raffles,

2. An extensive description and commentary on the formal legal order is available in J. H. Carpentier-Alting, Grondslagen der Rechtsbedeeling in NederlandschIndie, 2nd rev. ed. (The Hague: Martinus Nijhoff, 1926). For a useful recent discussion of problems of pluralism in colonial Indonesia, some of it relevant to issues dealt with here, see Jacques van Doorn, A Divided Society: Segmentation and Mediation in Late-Colonial Indonesia (Rotterdam: CASP, Erasmus University, 1983). The Dutch may have owed to Continental civil law their proclivity for putting nearly everything into law. Its strong legislative bias contrasts with common law traditions with a judicial bias. English (or American) courts might distinguish invidiously in the application of "equal" law, suffering no more than the untriable charge of hypocrisy, but civil law codes and statutes must be clear and explicit.

3. See John Ball, Indonesian Legal History 1602-1848 (Sydney: Oughtershaw Press, 1982), esp. ch. 4. 
significant revisions were introduced after $1848-$ i constitution of sorts, new codes, judicial reorganization--as the result of a wave of liberalism emanating from Holland. Again in the early 1900s, during the Ethical period, legal reforms were set in motion. Seen from the ground of Indonesian society, how ever, most of these changes were merely refinements of the pattern established earlier. They were significant for the Dutch community, and at times made a difference to Indonesians (e.g., the vervreemdingsverbod of 1870 , which forbade alienation of Indonesian-held land) but never did they more than superficially challenge the elemental distinctions of colonial economic, social, and political pluralism. Usually, they ended up reinforcing these distinctions in more sophisticated and subtle ways.

The logic of Indies pluralism and indirect rule required that Dutch and Indonesian communities be well equipped with the institutions they needed to play their appointed roles, but that the Indonesian side must be readily subordinated to that of the Dutch. This meant two bureaucracies, one subject to the other, including two judiciaries similarly related. The superior Dutch administration was the more complex. Part of it was independently responsible for external trade and commerce, colonial policy, and the internal affairs of the Dutch community, which after 1848 was accorded the rights and obligations enjoyed by citizens of the Netherlands, and the other part, the Binnenlands Bestuur, was responsible for direction of the Indonesian side. The Indonesian administration in Java consisted of the locally evolved pangreh praja, organized by kabupaten and principality, and outside Java, eventually, similarly coopted and reworked local bureaucratic instruments. The Dutch and Indonesian bureaucracies were organizationally and ethnically distinct, but were related structurally in an intimate hierarchy.

There was a similar relationship in the judiciary, with the important difference that ethnic boundaries were crossed in one direction. On the Dutch side was a judicial hierarchy, consisting of a first instance Residentiegerecht, the appellate Raad van Justitie, and the Supreme Court (Hooggerechtshof) in Batavia. The last two courts were staffed by trained lawyers linked increasingly by education, tradition, lore, style, and jurisprudence to the home rechtsstaat in Holland. Their jurisdiction extended to disputes over all external and most internal commerce, civil relations within the European community, and, of course, crimes committed by Europeans. The Raden van Justitie, which eventually numbered six throughout Indonesia, also heard appeals from the highest courts for Indonesians--demonstrating clearly where authority lay in that relationship. (From the Raden van Justitie further appeals were possible to the Hof, as the Supreme Court was familiarly known.) In criminal matters the Dutch prosecution (Openbaar Ministerie) was made up of trained lawyers (officieren van justitie) headed in Batavia by a Procureur-Generaal, who assumed responsibility also for the colonial police.

The Indonesian side of the governmental judicial system was truncated, for the highest judges were Dutch and appeals escaped into the European courts. There were three government courts for Indonesians: the district court for minor cases; the regency court for more substantial issues; and finally the Landraad in each kabupaten seat. To the Landraad came all significant criminal and civil matters among Indonesians and those assimilated to Indonesian status. Eventually all Landraad chairmen were trained lawyers, but until the 1920 s all of them were also Dutch, an element actually of direct rule. In part dictated by the absence of legally trained Indonesians (though in the nineteenth century Landraad judges were of ten local administrators without legal training), the use of Dutch judges was intended to assure fair justice and government 
control over local conflicts. During the 1920s and 1930s Indonesian lawyers did become Landraad chairmen, although they never made up a majority. 4 All other officials in the Landraden were Indonesian-the clerk, an Islamic penghulu as adviser, assorted assessors from the kabupaten offices, the bupati himself ex-officio, and the untrained jaksa, or prosecutor, who sat beside the judge as an assistant in criminal prosecutions. By contrast with the Dutch courts, the Landraden were relatively informal affairs, reflecting in part a Dutch view of Indonesian legal customs and social needs.

All these courts were established by the colonial administration. Other judicial institutions that predated government justice existed for Indonesians: customary (adat) courts, mainly outside Java, and Islamic courts both in Java and $a$ few other places. 5 Until the late nineteenth century the government usually left them alone. Thereafter, however, although in appearance autonomous, in reality both adat and Islamic justice were subjected increasingly to regulation and control. Final appeal rested with the Dutch judiciary, in the same way analogously as all local political orders eventually were subordinated to colonial administration.

Opposition to the plural judicial system never disappeared, but it never amounted to much. If inertia alone could not sustain the complex arrangement, pluralist ideology and interest added sufficient protection. Only the Landgerecht, established in 1914, had a common jurisdiction over all population groups, but it heard only minor misdemeanors. No more than a symbolic concession to liberal egalitarian ambitions, it was otherwise meaningless. Actually to unify the courts would have been a stunning blow, not so much to economic interests, by then perfectly capable of protecting themselves in any kind of judicial organization-most judges and all notaries and private lawyers were Dutch until the mid-1920s--but to precious stakes in racial, social, and political status throughout the colonial establishment.

The nature of these stakes was evident in the substantive law on which the distinct courts rested. Plural law practically and symbolically distinguished sharply, though never completely, between the several ethnic communities of the Indies. When in the 1840 s yet another proposal was made to apply Dutch law to everybody, one objection raised was that the different courts could not apply the law equally well. 6 Such reasoning obscured the issue. More to the point, if the law was the same for all, separate courts made doubtful sense. Different courts guaranteed different law, which was essential in the Indies colonial system for at least three reasons. First, it was only equitable; and otherwise people denied their own law might rebel. Second, it maintained the political dimensions of the different communities. Third, separate legal regimes helped to differentiate the economic roles of the major

4. In 1939 , of a total of 75 Landraad chairmen in the colony, 47 were Dutch and 28 Indonesian. Regeerings Almanak voor Nederlandsch-Indie 1939/II.

5. On adat courts see B. ter Haar, Adat Law in Indonesia (New York: IPR, 1948), esp. the introduction by Hoebel and Schiller; on Islamic courts, Daniel S. Lev, Islamic Courts in Indonesia (Berkeley: University of California Press, 1972).

6. In fact, this was a minor concern and probably an obfuscation. A more telling objection to legal unification was that it would cost too much in time and money, as the judges, usually also administrators at the time, would have to begin to study law more seriously. See Ball, Indonesian Legal History, pp. 206 ff. and 213-14. 
population groups. Access to Dutch law implied equal opportunity to engage in commerce of any kind, which made no sense at all in the cultivation system and not much more in the liberal era. Although in defense of the principle "to each his own law" the equity issue was raised most of ten, there is good reason to suppose that economic and political considerations were more pertinent.

"To each his own law" did not work simply, but for reasons that were clear and logical. The complexity of colonial pluralism bred legal complexity in equal measure. The basic principle was adat law for Indonesians and those classified as natives, and Dutch law for Europeans and those classified as Europeans. Put this way, however, the emphasis is on substantive law, which generally attracts more attention; but more significant differences may be found in the law of procedure, which critically defines relationships between those with and without authority. European subjects had two procedural codes, one for civil (Burgelijk Rechtsvordering) and the other for criminal (Strafvordering) matters. From the $1850 \mathrm{~s}$ these codes incorporated the provisions, including guarantees of personal rights, of the codes in Holland. For Indonesians one code sufficed for both civil and criminal issues, defining the procedures of the pangreh praja as well as the Landraden and lower courts. This was the Indisch Reglement, promulgated in 1848, revised in 1926, and further amended in 1941 as the Herziene Indisch (Indonesisch) Reglement, referred to hereafter as the H.I.R. Less complex and detailed than the procedural codes for Europeans, to serve the "simpler" needs and standards of Indonesians, the H.I.R. also provided far fewer protections against government authority. 7 It was easier, for example, to arrest, detain, and convict an Indonesian under the H.I.R. than a Dutch subject under the Strafvordering.

To whom exactly did these codes apply? A few examples will illustrate how the law accommodated disparate ethnic relationships in the colony. For one thing, the Indonesian community could not be treated as a solid unit. Church lobbies wanted Indonesian Christians to be assimilated to Dutch legal status, but as this threatened to open a huge can of worms, converts had to be satisfied with their own marriage law regime but no more. It was different with the Indonesian elite, whose alliance with the colonial administration was essential to indirect rule and who therefore required special consideration.

7. The argument in favor of simpler procedure to manage "simpler" needs and knowledge seems more sympathetic than it was. Whose needs actually were simpler and in what sense? Why did Indonesians need fewer guarantees and protections than the Dutch? Procedural law consists mainly of instructions to officials, not laymen. It is true that, during the nineteenth century, few officials in charge of Indonesian affairs were trained lawyers, but there were not many lawyers elsewhere in the administration either. Nor when more trained lawyers became available did the procedural law for Indonesians greatly improve. A principal reason for "simpler" procedures was clearly to afford Indonesians fewer means of protection than were available to Europeans against the government itself. During the late 1840 s Governor-General Rochussen objected to any introduction of Dutch procedural law for Indonesians because it would allow them "so many rights, independence and control" that they might begin to question their condition in ways distressing to the government. (Ball, Indonesian Legal History, p. 214.) They might conceivably also begin to question the authority of colonial and indigenous administrations. This risk was never taken. The procedural law of Indonesians and Europeans always remained quite different, a sound reason for maintaining separate courts. 
The high Javanese aristocracy, including all bupati, the highest Indonesian officials and advisers in the central bureaucracy, and senior Indonesian military officers were all exempted from the H.1.R. criminal procedure and provided with a "privileged forum" in Dutch courts, where the procedural rules for Dutch subjects maintained. In effect, while the Indonesian elite assimilated themselves socially to the fashions, styles, and habits of the Dutch community, the law also assimilated them politically.

In addition, not everyone in the colony was either Dutch or Indonesian. Ethnic Chinese, economically important and useful but otherwise unpopular, had to be linked economically to Dutch interests but kept at arm's length in every other way. There were also Arabs, Indians, and Japanese. As the position of these groups--ethnic Chinese and other "Foreign Orientals"-was problematic, their legal classification was not elegant. If for most purposes they were regarded as "natives," they were engaged in the same commercial traffic, though usually in untidy vehicles and on sidestreets, as Dutch entrepreneurs. Accordingly, they were treated as Indonesians in criminal law, but as Europeans in commercial law. The Japanese were an exception only because of Japan's growing power. Under pressure from Tokyo, they were assimilated fully to European legal status. Ethnic Chinese sought the same symbolic social and political parity, but neither they nor China had the leverage to pry it from the colonial administration.

Whatever else may be said about this legal maze, it recorded accurately the economic and political arrangements fashioned by Dutch power from the eighteenth century onwards. But the picture presented above is unadorned, lacking any of the ideological patina that developed with the colony and its legal establishment. As in any legal system, bedrock interests in the colony were obscured more and more by the rhetoric of many debates (especially with the onset of the liberal period and the arrival of more lawyers) over which law for whom, the intricacies of conflicts theory, the nature of equality between the plural legal orders, and much else. Once engaged, the gears of the legal system spun their own logic, of ten quite genuine in the way of legal logic, serving to legitimate and excuse a less gratifying reality underneath. 8

8. Almost from the start, for example, colonial administrators and apologists insisted that the plural legal orders were, in effect, separate but equal; and there were logical consequences of this view that could be cited in support of it. Thus, in civil cases with mixed litigants the law of the defendant applied, with the result that a Dutch plaintiff might have to sue an Indonesian in the Landraad. Whether or not adat law applied, however, depended on the nature of the dispute, for certain commercial processes were governed only by Dutch law. Indonesians could submit voluntarily to Dutch law in whole-which few ever did-or in part. Any who engaged in commerce, using bank drafts or bills of sale, for instance, were assumed to have submitted partially, for these purposes, to the Dutch law of commerce. As the new adat law policy (see below) developed in the twentieth century, the assertion of equality between adat law and Dutch law grew more insistent. It had much influence in the development of the fascinating intellectual edifice of intergentiel recht (interracial, or more precisely, interethnic law) replete with rules for working out conflicts between members of different law-groups. Its creator was the good-willed jurist $R$. D. Kollewijn--see his collection of essays from the late 1920s through the early 1950s, Intergentiel Recht (The Hague and Bandung: van Hoeve, 1955)-who insisted throughout that no distinction of quality must be made among the various bodies of substantive law in Indonesia. Yet this made little sense except to the most 
Reality had mainly to do with maintaining a manageable mass of Indonesians in place, and then, increasingly, also with assuring the political and social status, security, and future of the Dutch presence. Although of ten challenged, by some for standard liberal reasons and by others because a unified state seemed a better means of keeping control over a colony grown politically volatile, the plural legal system held up until the Japanese occupation. Along with the many interests encrusted around the principle, it is important to recognize how much it had become part of the defining ideology of the colonial state, imbedded in the body of law and legal doctrine that even non-lawyers came to take for granted.

\section{Adat Law Policy}

The treatment of local customary (adat) law is one of the most perplexing and ambiguous themes in Indonesia's colonial history, and deserves serious reconsideration. 9 In most colonies customary law was problematic in one way or another, but nowhere more so than in the Netherlands-Indies. And nowhere was more done to understand local law, that neglected so many critical questions.

The chief difficulty with most analyses of the adatrechtpolitiek is their isolation of it from the rest of colonial policy, as if it were somehow an issue apart in the colonial environment. In legal perspective, the basic question seems to have been whether or not to respect local law. But if that were the only issue, it can be argued reasonably (and with comparable naivet 6 ) either that the Europeans should have gradually overridden customary law in favor of a wholesale "modernization," or that it was only fair always to allow people to live by their own law. In colonial Indonesia both cases were made, again and again, of ten honestly, sometimes disingenuously. When one asks what difference the choice actually made for most Indonesians, answers are much more difficult to come by. As Furnivall observed of the contrasting approaches to welfare in Burma and Indonesia, in neither case were most people likely to benefit much. For the real issue was not legal but political and economic, and this the law helped persistently to obscure.

Seen in isolation, especially in colonial circumstances, local law is easily divorced from its own economic and political environment. Law, legal

blindered legal minds. Dutch law was a great deal more equal than all other law because Dutch authority was behind it: What, after all, was the premise behind the principle that Dutch judges might reject an adat rule that violated "civilized" moral commandments? (Judges now have similar authority to heed their own "conscience.") Moreover, colonial racial stratification left no doubt in anyone's mind, perhaps not even in Kollewijn's, that legal equality was not the real order of things. The principles of interethnic law survived into independence along with plural law itself. See Gouw Giok Siong, Hukum Antar Golongan (Jakarta: Penerbitan Universitas, 1959). But their influence within the legal system declined, particularly under Guided Democracy, as issues of national unity became politically more prominent. Ideologically, the idea of intergentiel recht serves subtly to preserve plural law. The strongest opposition to it in independent Indonesia has always come from lawyers who favor both legal and social integration.

9. A major critique of colonial law in Indonesia, including the adat law policy, should soon be available in the work of Peter Burns from James Cook University in Australia. See, for example, his "The Myth of Adat," May 1982, mimeo, a paper delivered at the Australian Asian Studies Association meetings. 
process, and political authority are everywhere essentially inseparable, but in the colonies local authority was unhinged from local interests and attached, in some measure, to the colonial power. Wherever this happened, customary law inevitably lost integrity. It became folk-law, still important as the repository of kinship organization and values, inter alia, but with little capacity for internal evolution and elaboration as conditions changed. Putatively the law of about 90 percent of the people, the adat law of Indonesia, as it has been known for nearly a century, is fundamentally a Dutch creation. By this I do not mean that substantive adat rules--of inheritance, say, or exchange--are other than Indonesian in origin, but that the understanding of adat, the myth of adat, as it were, and the relationship between adat and state authority are the result of Dutch, not Indonesian, work.

How far adat law was removed from Indonesian hands is evident in the drama made of adat law policy by the famous Leiden scholar, Cornelis van Vollenhoven. (It is, of course, perfectly understandable, under the circumstances, and no one made anything of it at the time, but the fact that a scholar in Leiden determined what would happen to the legal traditions of Javanese, Bataks, and Minangkabau, among others, is worth thinking about.) His influence merits more critical reflection than it has generally received. 10

Brilliant, complex, idealistic, even romantic, Vollenhoven incorporated into his work the most paradoxical implications of law in a plural society. He knew the adat law well, but visited the colony only twice, very briefly, and may not have understood fully the subterranean social and political tensions of the racial mix there. As much as he was loved and admired by his Indonesian students in Leiden, most of them ultimately ignored his vision. Out of genuine respect for Indonesian cultures, he nevertheless helped to imprison them in a cage of elegant policy that rendered them even more vulnerable to outside manipulation. Many thinkers on today's left (and some on the right) might appreciate Vollenhoven. Committed religiously and philosophically to a worlc of cultures different but equal, he came, I think, to see the modern state as a terrible threat to local history, imagination, and law. He seems to have wanted to spare Indonesia that fate.

Vollenhoven became directly engaged with problems of Indies legal policy as the result of a renewed debate, early in the Ethical era, over the issue of legal unification for all population groups. The Ministry of Colonies in The Hague had submitted to Parliament a proposal to prepare a unified civil code for Indonesia. Two strands of opinion in the colony supported this project: on the one hand, a liberal view that Indonesians should be drawn into the modern world of commerce and civil relations, where, subject to the same law, they would learn to compete along with the Dutch, ethnic Chinese, and everyone else; and on the other, an equally long-lived but harder-nosed view that unified law--Dutch law--would make for more efficiency and smoother commerce. It is also possible that, by this time, some interest had begun to develop in creating a more autonomous colonial state, of which an integrated legal system and unified law would be advantageous attributes. 11 In any event, Vollenhoven responded with a blistering attack, arguing that there should be "no lawyer's law for the Indies," because it was not their--the Indonesians-law, no unified

10. For a superb introduction to Vollenhoven and his work, see J. F. Holleman, ed., Van Vollenhoven on Indonesian Adat Law (The Hague: Nijhoff, 1981).

11. See van Doorn, Divided Society; and Eduard J. M. Schmutzer, Dutch Colonial Policy and the Search for Identity in Indonesia 1920-1931 (Leiden: Brill, 1977). 
code that would supersede the many local customary law regimes of distinct cultures. Instead, he insisted, the colonial administration must devote serious attention to understanding local law and preserving its integrity. After a few years of debate Parliament adopted Vollenhoven's adatrechtpolitiek, which promoted new understandings of adat law, new research, the training of Dutch and Indonesian adat law scholars, and even new adat law institutions.

It has never been altogether clear why Vollenhoven won and the unifiers lost on the issue, for the merits can be argued plausibly either way; and as Sonius has recently written, the reasoning of Nederburgh, who made the strongest case for unification, turned out in time to be more firmly based. 12 The influence of Ethical principles helped, for the adat proponents appeared to be more sympathetic to Indonesia, and more knowledgeable about local cultures, than those who favored unification. Yet Vollenhoven's ideas, although elaborately engaged with and attentive to adat law, did not lead to policies fundamentally different from those of the previous two centuries. They were only better informed and committed to a fuller cultural understanding of adat than most colonial administrators had bothered to develop. But if it was clear from experience that the policy of respecting adat had not helped Indonesians much, what reason was there to suppose that deepening it would help them more? (One answer to this question turns, of course, on what "helping" Indonesians meant.) Indirect rule and economy of administration had always validated the VOC's determination not to interfere with local law, so long as it did not impede Dutch interests or upset their cultural sensibilities. Most Dutch officials may not have understood adat well, but that was hardly their purpose in Indonesia. Much has been made of the fact, most recently by Ball, following Vollenhoven's critique, that Dutch ignorance of adat led to injustice for Indonesians. But knowledge of adat was irrelevant to the reality of economic and political domination. Whether adat was wholly indigenous, for example, with less Indic or Islamic influence than nineteenth century administrators had supposed, was not a question that greatly affected the welfare of most Indonesians. Colonial adat law policy had always helped to define Indonesian communities in ways that kept them manageable, even docile, and subject to authorities upon whom the administration could rely. With the best of intentions, Vollenhoven's reforms did no less.

Politically, the critical implication of Vollenhoven's adatrechtpolitiek was that it bore no critical implications for colonial administration and political structure. I mean to suggest that his views were adopted largely because the colonial bureaucracy and interests associated with it favored his position, which they recognized as one of no fundamental change. Ironically, the real reformers (in the abstract, at least) were less knowledgeable, less sympathetic, and less committed to Indonesian traditions, like many Indonesian nationalists themselves, including a few who later went to Leiden for training. On the side of the adatrechtpolitiek were the pangreh praja and Binnenlands Bestuur, for whom--sometimes out of genuine concern, sometimes self-interest-adat diversity was a principal justification of the administrative state in a plural society. The new adat law policy, then, was as much (or more) grounded in conservative political and social interests as in Ethical principles.

Admirable ethnographers but poor policy makers, the adat law activists, once in charge, proceeded to demonstrate how conservative, even reactionary, the adatrechtpolitiek really was. It may not have been Vollenhoven's purpose, but

12. H. W. J. Sonius, "Introduction," in Holleman, Van Vollenhoven, XXIX-LXVII, esp. at XXXVI-XXXVII. 
in the colonial context it is hard to see how it could have worked differently. Although he and others always insisted that they did not want to erect an adat museum in Indonesia, this is what their work tended to do. Determined to demonstrate that adat was relatively free of external influences, they could not easily make a case for change; with a few exceptions, they seldom did. In some areas, among them the Batak lands and Lampung, the policy led to the extraordinary initiative of reviving adat courts that had already disappeared, vesting authority over them in conservative local elites supported by the Binnenlands Bestuur.

Moreover, the adatrechtpolitiek had a distinct political edge, though always denied, that was evident in its treatment of Islam. Vollenhoven himself argued that "The destruction of adat law will not pave the way for our codified law, but for social chaos and Islam." 13 Partly from a theoretical animus against admitting alien influences into local adat law, but also from fear, both Dutch and local, of Islamic expansion, the adat law scholars spent much intellectual energy proving that Islam had made few inroads into adat. This was not a realistic or even theoretically sensible view of the interweaving evolution of Islamic and other values in the changing societies of Indonesia. But it served to transform adat increasingly into the conservative legitimating symbol of local authorities, who appreciated the help, against Islamic challenges. Islamic institutions, as much as was politically possible, were contained and subordinated by a reception theory that made Shariah rules valid only to the extent that they had been assimilated by adat. This was not the endogenous outcome of Indonesian social and political processes, but of colonial policy, usually in collaboration with Indonesian allies.

There was, further, the irony that an adatrechtpolitiek intended to keep local law in local hands actually reinforced the authority of Dutch-controlled institutions over that law. As adat law was understood theoretically to persist best in the closed community, the adat researchers tended to write as if local communities were closed. Reading these studies from the 1920 s and $1930 \mathrm{~s}$, thorough as many of them are, one is seldom aware of the surrounding Dutch presence of administrative authority, economic enterprise, commercial power, social influence, and cultural example. The writers, like TV cameras, of ten even seem to deny that they themselves are there. But the villages were not closed communities; and the adat law itself was peculiarly theirs but not theirs. The degree to which it had become a product of Dutch authority was evident in the establishment of adat courts by the colonial administration, in the review of adat decisions by the Landraden, in the rendering of decisions in adat issues by Dutch Landraad judges, in the presence of Dutch officials at adat court sessions, in the remarkable research on adat that was done by Dutch scholars and by Indonesian scholars trained by Dutch teachers, all of whom wrote in Dutch. Once written, moreover, the adat research violated a primary principle of adat law theory, that the adat lived in local tradition. Now, written, it lived in books, which Dutch judges, and Indonesian judges half a century later, used as if they were codes. 14

13. In Holleman, Van Vollenhoven, p. 122.

14. Moreover, adat law research, because it tended to focus on substantive law, of ten missed the fundamental importance of legal process--i.e., how "rules" were negotiated, manipulated, adjusted, and changed in practice to suit circumstances. In this way, too, local law was frozen conceptually the moment it was written down and the reports used as if they recorded legal reality. 
Indonesians with the education and leisure to think about adat divided on the issue. Those who worked in and for the government--administrators, scholars, judges-favored the adatrechtpolitiek, in which they were frequently involved. Private lawyers and intellectuals were much less favorable toward it. 15 Indonesians of higher status increasingly came to regard themselves as free of adat, legal classifications to the contrary notwithstanding. In their view, very often, adat belonged to backward villages, not the modern urban centers in which they made their lives. As for local people in the villages, whose adat presumably it was, when the revolution came, in some places they took the initiative to obliterate adat courts-and sometimes also the authorities who ran them--and demanded, occasionally to their later regret, the "national" institutions of the new state. 16

\section{Indonesian Private Lawyers and the Colonial Legal System}

The rigorous consistency of the dual legal system is evident in the maintenance of its boundaries. The ethnic division of labor was such that Dutch officials might, of course, penetrate the Indonesian side, but not the reverse. In fact, however, few officials crossed from one side to the other at all. Only one Indonesian judge, late in the 1930s, moved to a Raad van Justitie, and none ever to the Hof. 17 The officieren van justitie were all Dutch. On the Indonesian side were pangreh praja officials, jaksa, Islamic penghulu, assorted clerks, and, along with Dutch judges, legally trained Indonesian Landrechters.

The same was true, with one significant exception, of the private legal professions. Of these there were three: notaries, bush-lawyers (pokrol-bambu), and advocates. The first two illustrate the argument perfectly, the advocates less so and for that reason they are particularly interesting.

The notaries, the key private (but publicly licensed and regulated) lawyers in civil law systems responsible for drafting "authentic documents," always sat comfortably and securely ensconced in the centers of urban European commerce governed by the civil and commercial codes. Few in number and invariably Dutch, they seldom extended their services beyond the European community, except to those who specifically assimilated, in whole or in part, to European legal status. Professionally insulated, both functionally and ethnically, notaries saw little reason to know much about or to bother with the Indonesian side of the legal system.

15. See, for example, Takdir Alisjahbana, Indonesia in the Modern World (New Delhi: Congress for Cultural Freedom, 1961), esp. pp. 100-109, "Confusion in Legal Thinking."

16. Daniel S. Lev, "Judicial Unification in Post-Colonial Indonesia," Indonesia 16 (October 1973).

17. J. S. Furnivall wrote that since 1917 Indonesians could serve as judges on the Hooggerechtshof and Raad van Justitie. See his Netherlands-India: A Study of Plural Economy (New York: Macmillan, 1944), p. 296. Legally they could, but in practice they did not until more than two decades later, when R. Kusumaatmadja was promoted to the Raad van Justitie of Batavia, though I am uncertain when (or whether) he actually served as an appellate judge. He later became Indonesia's first Supreme Court chairman. 
Pokrol-bambu were entirely on the Indonesian side. 18 They were banned from the European courts by a rule requiring trained counsel there. In courts for Indonesians, however, anyone at all could serve as counsel. The existence of pokrol-bambu, untrained lawyers of varied origins, attested clearly to an Indonesian need for some means of access to foreign-dominated institutions, and also to an ability to imitate effectively the most suitable professional role for it. All that pokrol-bambu required was rudimentary Dutch, some understanding of how colonial institutions for Indonesians worked, and personal confidence. Despised as they were, pokrol-bambu survived because they could not be prevented, under the simple recognition that people could not always represent themselves. Similar figures seem to have emerged in all colonies. In Indonesia they were hated by trained advocates, judges, and especially the pangreh praja, who saw, and still see, them as trouble-makers, cheats, and pettifoggers who encouraged disputes and litigation. But then as now another reason for their unpopularity in high places was the view that most Indonesians should not require private lawyers at all. Why should they want this kind of private legal initiative if the administration was adequate to their needs? Pokrol-bambu were lively proof that it was not adequate, and by their work made a mockery of claims by officialdom to govern caringly a satisfied population.

Indonesian advocates were a different matter. The colonial administration discouraged Indonesian lawyers from private practice, and Dutch advocates, for obvious reasons, thought the idea abominable. Legal training for Indonesians, introduced in 1908--though a full course law faculty was opened only in 1924-was intended to produce public lawyers for bench and bureaucracy on the Indonesian side. Most Indonesian lawyers did join the government services, but no one could stop the rising number who chose to enter the private profession after the first opened an office in 1923.19

Indonesian advocates were among the few lawyers who knew both sides of the colonial legal universe well enough to assess them and their social and political foundations critically. The first Indonesian professionals to succeed in the liberal economy, they practiced mainly in the courts for Europeans, but also in the Landraden, where many of them had also had experience as clerks before taking their degrees. They were almost alone in traveling back and forth between the two sides with an interest in comparing them. They preferred the Hof and the Raden van Justitie.

The choice is not surprising. Anyone could practice in the Landraden, but only a select few could appear before the higher European courts, where lawyerly skills paid off handsomely in money, respect, and a new kind of status for

18. On pokrol-bambu, see my Bush-Lawyers in Indonesia: Stratification, Representation, and Brokerage (Berkeley: Law and Society Program Working Paper no. 1, 1973).

19. See Daniel S. Lev, "The Origins of the Indonesian Advocacy," Indonesia 21 (April 1976). The actual number of practicing Indonesian advocates was never very large, but their influence in a small elite was considerable. In 1942 there were 194 professional advocates in Indonesia (down from a peak of 203 in 1939), of whom 122 were Dutch, 36 ethnic Indonesian, and 36 ethnic Chinese. The proportion of Indonesian advocates (both indigenous and ethnic Chinese) in the profession rose from 3.07 percent in 1925 to 37.10 percent in 1942 , which undoubtedly helps to explain why Dutch advocates were unhappy about the new recruits. The numbers were compiled from the Regeerings Almanak voor Nederlandsch-Indie for those years. 
Indonesians. They were private professionals, however, and not easily coopted. Most Indonesian advocates were nationalists of one kind or another--usually the PNI kind--and later, during the revolution, when many former Landraad judges and administrative of icials crossed over to Dutch territory, very few advocates did so. But liberal European legal institutions were altogether to their liking; and it was clear to them that old Indonesia, or the Indonesian side of the plural order, was no longer tenable. From the start they were contemptuous of local adat and adat institutions, the pangreh praja, and, in general, those educated Indonesians who chose comfortable careers in the bureaucracy rather than stand on their own. To the minds of Indonesian advocates, the differences between the Dutch and Indonesian sides of the colonial legal system were unambiguous. On the one side were legal equality, personal rights, challengeable authority, knowable written law, and various sorts of opportunity. On the other was the privileged authority of officialdom, where discretion counted for more than law and influence peddlers more than lawyers. The vision of private lawyers, borrowed unashamedly from Europe and very compelling, was of an independent Indonesia where law superseded discretion, personal ability superseded privilege, and society was not superseded by the state.

\section{Independence and the Indonesian Side State}

With independence, Indonesia had two legal traditions to choose from. Indonesian advocates and many other intellectuals wanted a state modeled essentially on the European side of the colonial legal system. Instead, the Indonesian side won out, laden with the legal instruments and, more subtly, the political assumptions by which Indonesians had been managed in the Netherlands-Indies. In the corpus of substantive law retained by the Republic, the plural society of the colony lived on; and in the institutions that survived the revolution so did the most repressive side of colonial political structure.

The failure of the revolution to demystify the colonial heritage completely accounts in large part for the ease with which the old forms were adopted. In the nature of legal systems, concepts and structures developed in one age carry over as myth thereafter, transforming what were once straightforward matters of interest and power into principles and habits. These may be challenged by new groups entering politics--outsiders suddenly mobilized by revolutionary ideas and opportunities, for example--but usually not by insiders to the heritage unless, for good revolutionary reasons, they have developed a compelling ideological alternative. Often it does not occur even to reformers to challenge ideas whose origins were in serving the interests of the power that wrote them into law.

Nothing more clearly indicates the lack of a new ideology of state, society, and economy, or the absence of a consensus on one, than that the substantive law of post-1945 Indonesia remained almost exactly the same as it was in 1941. Important procedural changes aside, an oblivious attorney could take up in 1950 (or for that matter decades later) as if the war, occupation, and revolution had never happened. The criminal code was nearly pristine, except for a few changes--e.g., "Queen" and "Governor-General" were amended to read "President" and "Vice-President," and the like. 20 So were the civil and commercial codes, applying mainly still to Europeans, ethnic Chinese, and partial others. As

20. The criminal code and other criminal provisions were amended in Law 1/1946, in Koesnodiprodjo, Himpunan Undang2, Peraturan2, Penetapan2, Pemerintah Republik Indonesia, vol. 1946 (Jakarta: Seno, 1951), pp. 1-7. 
far as anyone knew, the adat law applicable to most Indonesians was also the same as before. Without new statutory instructions or policy direction, the courts picked up as before, invoking the codes here and adat there and conflicts rules when litigants or issues were mixed.

Retention of the old law was not a matter of oversight. It was stipulated explicitly in the first constitution of 1945 and the succeeding two of 1949 and 1950, with the odd result that the law in force frequently contradicted constitutional provisions--e.g., with respect to human rights. Indeed, one can argue realistically that the effective constitution of Indonesia consisted not in the constitutions at all but in the corpus of statutory law, legal principles, and institutions inherited directly from the colony. Why were fundamental changes not introduced immediately, at least to the extent of drafting new basic principles for later elaboration? In the preparatory committees established during the Japanese occupation there were in fact proposals for significant changes of legal principle, most notably by the nationalist lawyer Muhammad Yamin, whose ideas then were similar in important respects to those of the liberal unifiers of the colonial past. They were rejected largely on basis of arguments by the famous adat law scholar, Supomo, whose very conservative views were rooted deeply in the colonial Indonesian side establishment. 21 That Supomo won, with support from Soekarno, among others, can only be attributed to a predilection, particularly among Javanese political leaders in the revolutionary heartland, for the assumptions that governed the Indonesian side. They had not come up with anything new that made as much sense to them as what already existed, except of course for a radical change in state leadership.

Plural substantive law, for example, provided the clearest ideological blueprint of colonial pluralism. Why was it left in place, evidently without a great deal of thought? Several reasons can be adduced, but two seem especially important. One is that without an obvious alternative, unifying the law seemed to demand a painful choice between the codes and adat as the conceptual base. 22 The codes were attractively "modern" but symbolically "European," and might still work to the advantage of European and ethnic Chinese commerce. Adat, which had been used to keep Indonesians in their place, could by a slight turn of imagination become a nationalist symbol of their distinctiveness, but it was generally regarded as too primitive for the law of a modern state. The dilemma favored the legal status quo until there was time to resolve the issues. So did the other reason, namely that most officials in the new state, particularly public lawyers in the administrative and judicial bureaucracies, took plural law and plural society for granted as the only working model they knew.

There was no lack of protest after 1950 about the continued force of "colonial" law. But in fact it had become Indonesian law, solidly grounded in interests well served by it. Judicial readings of adat law and the codes began to change, but not the basic classifications of population groups stamped into the inherited law. More than traces of these remain in modern Indonesian legal and political

21. See Muh. Yamin, Naskah Persiapan Undang-Undang Dasar 1945 (Jakarta: Prapanca, 1959) and his Proklamasi dan Konstitusi (Jakarta: Djambatan, 1951).

22. Whereas most public and private lawyers and legal scholars took it for granted that Indonesia, as a modern state, would eventually create a new legal system based on "modern" codes, a few adat scholars argued for adat law as the base. The most prominent among these latter was the late Professor Djojodigoeno of Gadjah Mada University. See, for example, his Reorientasi Hukum dan Hukum Adat (Yogyakarta: Penerbitan Universitas, 1961). 
ideology, not only among those who make policy and apply the law but also among those to whom it is applied. Ethnic Chinese remain "Foreign Orientals" more than citizens, and the law silently but consistently helps those interests vested in keeping them so. Christians of all ethnic groups also remain legally distinct, separated out for special treatment (mainly with respect to civil registry and family law) that suggests higher status, as in the colonial past, and contributes to their continued segregation from the majority Muslim population.

The problem of adat law in this connection is more subtle. Adat continued to invoke, symbolically, the racial criterion of the colony over against ethnic Chinese, whose law is written in the civil and commercial codes and special provisions. 23 But the succession of ethnic Indonesian political leadership necessarily implied the disappearance of racial and caste overtones in the relationship between state and ethnic Indonesian society. Racial domination easily mutated into class domination, however, for the legal system was ideologically suitable for either. As Indonesian political and social elites have long since ceased to feel legally bound by adat law, it has come to signify lower class, mainly rural Indonesians, conceived also more as objects of administration than as citizens.

While substantive law remained the same, the politically even more significant law of procedure did not, but for most people there was no change. The Japanese military administration had unified the judicial system, eliminating the European courts in favor of the Landraad, and retained the pangreh praja for much the same purpose it had served in the colony. This dictated also keeping the H.I.R. and scrapping the Dutch civil and criminal procedural codes. If these innovations facilitated, they did not predetermine what happened during the revolution. The early Republic was hardly bound by them, anymore than it was by others which it threw out. It might have broken the old molds of the legal system, eradicating the administrative structures of the colonial state and creating new ones. Instead, the politics of the revolution favored institutional continuity, which the occupation initiatives had in effect anticipated. The Binnenlands Bestuur, with Indonesian personnel, was merged into the pangreh praja, now become the pamong praja, and the European judicial apparatus was permanently shorn off. This left the Indonesian side of the colonial legal establishment intact, administered by conservative elements whose ideology and political style were shaped almost entirely by the colonial regime.

The pamong praja was the key institutional heritage that weighted the case in favor of maintaining colonial regime norms. It was the one institution without which those norms would be very hard to maintain. Early in the revolution Soekarno and Hatta reached an agreement with leaders of the pamong praja, which seemed critically important for mobilizing the people or, once mobilized, keeping them under control. 24 Thereafter, the pamong praja's odds of survival were

23. During the 1960s, however, the Supreme Court (Mahkamah Agung) began to view the codes and special legislation as a record of the adat law of ethnic Chinese, which allowed judges more leeway in reading change into the law. See Daniel S. Lev, "The Lady and the Banyan Tree: Civil Law Change in Indonesia," American Journal of Comparative Law 14, 2 (1965).

24. Benedict R. O'G. Anderson, Java in a Time of Revolution (Ithaca: Cornell University Press, 1972), pp. $112 \mathrm{ff}$. The original purpose of the pangreh praja in the colony was to manage Javanese peasants for the sake of efficient deliveries of produce. This is the task it always performed best and, in 
better than even, and if it survived so too would the spirit of local bureaucratic domination which it embodied. (Pamong praja officials, moreover, found their way into the central bureaucracy, judiciary, prosecution, and police, all of which were short of trained staff after the revolution.) Inclined to procedures that were not "legal"-in the liberal sense that persuaded advocates and many other reformers-but fundamentally patrimonial, discretionary, and authoritarian, the pamong praja remained for most Indonesians, after the revolution as before, their usual experience of the state.

The tension between contradictory principles represented by the pamong praja on the one hand and the postrevolutionary parliamentary system on the other probably meant that one of them had to go. With support from the army the pamong praja survived the onslaught of Law 1/1957, which subordinated it to elected local government, and the parliamentary system itself disintegrated. Thereafter, with political parties steadily weakening and the pamong praja securely in place, both Guided Democracy and the New Order were genetically linked to the structure of the colonial state. In this one respect, at least, the independent state was not merely similar to the colonial state. It was the same state.

Judicial institutions were less important politically, as they were on the colonial Indonesian side, but they illustrate a similar pattern with more texture. Not a great deal of attention was paid them during the revolution or afterwards. Private lawyers had wanted the Republic to adopt the European codes of procedure (in effect the European courts) as the base of the judicial system, for they knew them well and respected their rigor. These lawyers were overruled largely in the interest of practicality. Not only had the Landraden been the highest courts for Indonesians, giving them a slight nationalist edge, but the only available judges with experience had been Landraad judges, who preferred the courts with which they were already acquainted. There was considerable doubt that these judges, not to mention the many inexperienced ones who would have to be appointed, could manage the European codes well, hence, too, the H.I.R. Similarly, but more seriously with some hindsight on later problems of abuse of power, the new prosecution derived from the prewar jaksa, of whom the H.I.R. demanded so little that their indictments were subject to review and approval by first instance judges. 25

Like the pamong praja, the judiciary inherited a normative understanding of its role that, unlike the colonial courts for Europeans, did not allow for much institutional autonomy or disagreement with state action. Nor did the H.I.R. encourage anything of the sort. Still, the Landraden were closer in tradition to the Raden van Justitie than, say, jaksa were to officieren van justitie; and Landraden judges had the strength of legal education. When liberal parliamentary values seemed supportive, a few judges did assert their

important ways, still does. Yet reformers, both in the Ethical period and also now, tend to take the pamong praja for granted in efforts at change which it is most likely to subvert.

25. The H.I.R. revision of 1941 created a new prosecutorial parquet for the Indonesian side, modeled on the Openbaar Ministerie, but there was no time for it to develop before the Japanese army arrived. The reform went into effect in principle during the revolution and in practice, more or less, after 1950. But the procedural rules for jaksa were nowhere near so rigorous as those for the former officieren van justitie. 
independence and sought to expand the influence of the judiciary. 26 They were unsuccessful, however, for the parliamentary order soon collapsed and neither politically nor legally could the courts find ideological support for the greater institutional prominence they wanted. Although less speedily and far more resentfully than the prosecution, police, and pamong praja, the judiciary fell into line relatively easily with the terms of state established (or reestablished) under Guided Democracy and the New Order.

While the line of this argument can be drawn further, at some point it must become tenuous, for not everything is traceable to colonial origins. So far it does suggest something about cultural interpretations of Indonesian politics that reach to a far past rather than a nearer one. Even the most elegant and persuasive of such interpretations are elusive, just as Soekarno's assertion of an unadulterated Indonesian tradition vibrated uncomfortably with contrivance, because both try to skirt around the colonial history through which the old ideologies had to pass. If colonialism could not eradicate fundamental values in Java or anywhere else, it did filter and shape them, imposing new institutional forms of authority with their own ideological inferences that became inescapable terms of reference for those who eventually staffed the independent state. Does old Javanese patrimonialism have more influence than new colonial patrimonialism, or can the latter be mistaken for the former? Soekarno's Minister of Justice, Sahardjo, reached back to old Java for the banyan tree as a symbol of justice, but the institutions he had in mind to provide pengayoman (succor, protection) were the pamong praja and pengadilan negeri, whose law was the H.I.R., none of which it occurred to him to change in the slightest.

The New Order calls up the colonial comparison more than Guided Democracy did, partly because Soekarno kept pointing misleadingly to old Java (though Benda ignored him) but partly also because the present regime looks more like the colony in its relative efficiency, economic drive, effective political control, and even its superficial claim to rule by law. More than Soekarno wanted or was able to do, the New Order has also confronted Islamic and populist challenges in ways more sharply reminiscent of colonial style. But in both Guided Democracy and the New Order, despite the critical differences between them, the institutional pattern has been basically that of the Indonesian side of colonial rule. Legally, both regimes used and appropriately supplemented the repressive instruments of the criminal code much as Batavia had used them. There is not much evidence that anyone with authority has thought the Haatzaai Artiklen--criminal code articles that punish the "spreading of hatred" against political leaders, state officials, or ethnic groups--long detentions, directed judicial convictions, or even internal exile anything less than legitimate instruments of state. It is not simply that such legal provisions have been retained, but that their retention implies the same understanding of political prerogative from which they originated.

26. The first chairman of the Mahkamah Agung, Kusumaatmadja, mentioned above (note 17), defended the Court against any challenge to its independence or authority. He died in 1951, however, and his successor, Wirjono Prodjodikoro, a prewar Landraad judge, was much more inclined to accommodate political leadership. Another former Landraad judge, Suprapto, Chief Public Prosecutor (Jaksa Agung) until 1959, also tenaciously defended the autonomy of his institution against attempts to use it politically. His successors quickly changed course under Guided Democracy, turning the public prosecution into little more than a political instrument with a huge capacity for rapacious corruption. 
Opposition to the "Indonesian side" state still derives largely from the same sources as fifty or sixty years ago. Professional advocates (though by no means all of them) are the most articulate critics from within the legal system. Anti-plural law and pro-limited state, the ideological commitments of many advocates remain more or less firmly imbedded in the values of the European side. The parliamentary system was much to their liking; they still look back on it as very promising. They have persistently demanded legal reforms along the lines of the old procedural codes for Europeans, and political reforms that are best understood by reference to the liberal ideas that underlay these codes. Some of the changes they seek have actually been achieved, to the limited extent at least that they now appear in Law 14/1970 on judicial organization and the new code of criminal procedure, Law 8/1981, the first major code revision since the colonial period. Support for these reforms comes primarily from a growing middle class with an interest, how ever ambivalent, in imposing limits on the exercise of state power. 27

The promise of reform, however, is seriously confined, now practically by the overwhelming power of the army to determine the extent and quality of change, but always also by a heritage of colonial administrative and legal tradition that remains alive in the institutions and ideology of the independent state.

27. See my "Judicial Authority and the Quest for an Indonesian Rechtsstaat," Law and Society Review 13, 1 (Fall 1978). 